\title{
Efficacy of Native Bacillus subtilis against Postharvest Penicillium Rot Pathogen Penicillium sp. of Khasi Mandarin Oranges in Meghalaya, India
}

\author{
Janshame Tariang*, D. Majumder and H. Papang \\ Department of Plant Pathology, School of Crop Protection, College of Post Graduate Studies, \\ Central Agricultural University, Umiam - 793103, Meghalaya, India \\ *Corresponding author
}

\section{A B S T R A C T}

\begin{tabular}{|l|}
\hline Ke y w o r d s \\
$\begin{array}{l}\text { B. subtilis, } \\
\text { Penicillium rot, bio- } \\
\text { control, Khasi } \\
\text { mandarin, } \\
\text { Meghalaya }\end{array}$ \\
\hline Article Info \\
\hline $\begin{array}{l}\text { Accepted: } \\
\text { 07 November } 2018 \\
\text { Available Online: } \\
\text { 10 December } 2018\end{array}$ \\
\hline
\end{tabular}

Khasi mandarin orange is an important horticulture crop in Meghalaya but several losses have been reported due to the post-harvest disease Penicillium rot caused by Penicillium sp. B. subtilis was evaluated for its efficacy against Penicillium sp. under in-vitro. A total of 260 isolates were isolated from samples collected from different habitats of Meghalaya. Twelve B. subtilis isolates were identified by morphological, biochemical and molecular identification and studied for their antagonistic properties against Penicillium sp. The habitats of these $12 \mathrm{~B}$. subtilis isolates were recorded to befrom crop rhizosphere, mixed manure, fishery pond, mushroom compost and jhum area. Based on the antimicrobial traits, 6 B. subtilis isolates (Bs 167, Bs 197, Bs 217, Bs 219, Bs 256 and COB5Y1) were found with potential antagonistic properties as they were tested positive to chitinase and protease production. Bioassay showed that B. subtilis isolate COB5Y1 was recorded with the highest disease inhibition per cent against Penicillium sp. with $88.11 \%$ followed by Bs 167 (80.82\%) and Bs 197 (54.82\%). Four isolates COB5Y1, Bs 167, Bs 197 and Bs 217 were found with potential antagonistic properties as they could produce chitinase and protease and also were recorded with the maximum percentage of inhibition in dual test.

\section{Introduction}

Mandarin is a group name for a class of oranges with thin, loose peel which falls under members of a distinct species Citrus reticulata Blanco. Khasi mandarin in particular, is an important horticulture fruit crop in the NorthEastern (NE) parts of India. Meghalaya is the major state in the NE India for both area and production of Khasi mandarin (Singh, 2001). It is vastly cultivated in the outskirt and border areas of the state with an estimated area for its cultivation over 10,000 hectares and production of about 50,000 metric tonne (MT) annually. In India, the total area under cultivation for mandarin is 3.11 lakh hectare with the production of 29.06 lakh tons (Anonymous, 2013). However, Khasi mandarin constitutes about $43.6 \%$ of the total citrus fruits produced and occupies nearly $38.2 \%$ of the total citrus area in India (Anonymous, 2011).

Although Meghalaya is one of the largest producers of orange in the country, due to the problem of postharvest diseases, there are 
considerable losses to harvested fruits and the average yield of orange in India is alarmingly low as compared to other countries. Several reports have been published world-wide during the last two decades regarding the green and blue mould infections of harvested citrus (Citrus reticulata Blanco), the causal agents identified as Penicillium sp.

Green mould caused by $P$. digitatum is the major postharvest disease of citrus, wherever it is grown and causes serious losses annually (Eckert and Brown, 1986). In the NE parts of India, upto $30-50 \%$ losses of citrus was reported to be due to Penicillium rot caused by $P$. digitatum (Selvakumar, 2011). In Meghalaya, 17.75-19.28\% losses of Khasi mandarin was reported, due to Penicillium rot disease caused by $P$. brevicompactum (Barman, 2010).

B. subtilis is well known as one of the most active antagonist as it produces inhibitory substances and a large number of peptide antibiotics. The antibacterial-antifungal substances produced by $B$. subtilis has popularise its biological control potential against several phytopathogens that causes fruit decay. It is known to produce antibiotics such as iturin, surfactin, fengycin, enzymes that degrade fungal structural polymers such as chitinase, protease, $\beta$ 1-3 glucanase and antifungal volatiles which are antagonictic properties (Fiddaman and Rossall, 1993; Knox et al., 2000; Jiang et al., 2001; Pinchuk et al., 2002; Leelasuphakul et al., 2008).

The use of synthetic fungicides is the primary means to control postharvest diseases which is of public concern due to the accumulation of chemical residues in the food chain and environmental (Eckert, 1990; Arul, 1994).An alternative biocontrol method was studiedby screening the efficacy of $B$. subtilisagainst Penicillium sp.

\section{Materials and Methods}

Collection of samples, isolation of bacterial isolates and maintenance

Samples were collected from different habitats of Meghalaya viz., root rhizosphere of different available crops, hot springs, coal mines, jhum area, manure compost, mushroom compost, forest, lime stone mines and fruit surfaces (Sneath 1986; Leelasuphakul et al., 2008; Cihan et al., 2011).

Each $10 \mathrm{~g}$ of thesample was added to $90 \mathrm{ml}$ of sterile distilled water inconical flask and mixed thoroughly on a rotatory shaker for 5 min. Heat shock treatment was done for each sample i.e. heating the sample suspension in a water bath at $80^{\circ} \mathrm{C}$ for 10 mins (Kumar et al., 2012). Isolation for B. subtilis isolates was done on Nutrient agar (NA) medium by serial dilution (Sushma et al., 2012). The inoculated plates were incubated at $37 \pm 1^{\circ} \mathrm{C}$ for $24-48 \mathrm{~h}$ (Jamil et al., 2007; Munich, 2014). Maintenance of isolates were stored for long term in Nutrient broth (NB) containing 20\% (v/v) glycerol and at $-20{ }^{\circ} \mathrm{C}$ (Munich, 2014) and subsequently sub-cultured over a period of 3months (Gomaa and Momtaz, 2007)

\section{Identification of bacterial isolates as $B$. subtilis}

\section{Morphological identification}

A $24 \mathrm{~h}$ old colony of each isolate was picked up (loopful), mixed with $10 \mathrm{ml}$ of sterile water in a culture tube and vortex. Serial dilutions were made upto $10^{-7} \mathrm{cfu} / \mathrm{ml}$ and from the final dilution, $0.1 \mathrm{ml}$ was pipetted out in Petri plates containing NA medium. Each isolates was recorded for their colony characters in terms of colony colour, colony elevation, colony edges, colony consistency and shape of the bacterium(Holt et al., 1994). 


\section{Biochemical identification}

Gram staining test, catalase test and oxidase test was done for each isolates so as to screen for the interested B. subtilis isolates only.

Gram staining: Gram staining was carried out for all the isolates to differentiate the bacteria as Gram positive or Gram negativeby using the gram staining kit following the manufacture's instruction (K00-1Kt, Himedia). Microscopically at 10X, 40X and 100X (using oil) was observed for Gram positive or negative reactions and the shape of the cells was recorded.

Catalase test: A loopful of the test bacterial culture $(18-24 \mathrm{~h})$ and a drop 3\% hydrogen peroxide $\left(\mathrm{H}_{2} \mathrm{O}_{2}\right)$ were mixed on a clean glass slide. Observation was made for the production of gas bubbles (Schaad, 1992).

Oxidase test: The test was carried out by using oxidase disc (DD018, Himedia), where $24 \mathrm{~h}$ old bacterial culture was picked up with the help of ainoculation loop and rubbed on the oxidase disc. A change in colour of the disc was observed and recorded.

\section{Molecular identification}

The isolates were identified for Bacillus sp. using Bacillus sp. specific primerand for $B$. subtilis using $B$. subtilis specific primer

\section{DNA isolation}

The genomic deoxyribonucleic acid (DNA) of each bacterial isolate was extracted from bacterial suspension (after $12 \mathrm{~h}$ incubation in LB) using DNA extraction kit (Himedia) following the manufacture's instruction.

\section{Bacillus sp. specific primer}

The isolates were identified for Bacillus sp. using Bacillus sp. specific primer BCF1-
CGGAGGCAGCAGTAGGGAAT/ BCF2 CTCCCCAGGCGGAGTGCT TAAT (Cano et al., 1994). A PCR reaction mixtures $(25 \mu \mathrm{l})$ was prepared each containing 1X PCR buffer; $25 \mathrm{mM} \mathrm{MgCl} 2 ; 2.5 \mathrm{mM}$ dNTPs; each $10 \mathrm{pmol}$ primer; 3U Taq DNA polymerase and $100 \mathrm{ng}$ bacterial DNA. The PCR in a volume of $25 \mu 1$ was carried out with initial denaturation of 94 ${ }^{\circ} \mathrm{C}$ for $5 \mathrm{~min}$, followed by 40 cycles of program $94{ }^{\circ} \mathrm{C}$ for $1 \mathrm{~min}, 58{ }^{\circ} \mathrm{C}$ for $1 \mathrm{~min}$ and $72{ }^{\circ} \mathrm{C}$ for 1 min ending with 10 min extension at $72^{\circ} \mathrm{C}$. PCR reactions were run on a $0.8 \%$ agarose gel in $1 \mathrm{X}$ TBE and the observation for amplicon size $546 \mathrm{bp}$ was recorded using ultraviolet gel documentation system.

\section{B. subtilis specific primer}

Discriminating B. subtilis from Bacillus sp. isolates was then carried out using two sets of primers specific to $B$. subtilis EN1F (103-124 bp) 50 -CCAGTAGCCAAGAATGGCCAGC30; EN1R (1,413-1,393 bp) 50 GGAATAATCGCCGCTTTG TGC-30) (Ashe et al., 2014). A PCR reaction mixtures $(20 \mu \mathrm{l})$ was prepared each containing $1 \mathrm{X}$ PCR buffer (10mM TRisCl, $50 \mathrm{mMKCl}, 1.5 \mathrm{mM} \mathrm{MgCl}_{2}$ and $0.01 \%$ gelatin); $100 \mu \mathrm{M}$ dNTPs; each 10 pmol primer; $0.75 \mathrm{U}$ Taq DNA polymerase and 100 ng bacterial DNA). The touch down PCR in a volume of $20 \mu \mathrm{l}$ was carried out with initial denaturation of $94{ }^{\circ} \mathrm{C}$ for $5 \mathrm{~min}$ followed by 10 cycles of touch down program $\left(94{ }^{\circ} \mathrm{C}\right.$ for $30 \mathrm{~s}, 70{ }^{\circ} \mathrm{C}$ for $20 \mathrm{~s}$ and $74{ }^{\circ} \mathrm{C}$ for $45 \mathrm{~s}$, followed by a $1{ }^{\circ} \mathrm{C}$ decrease of the annealing temperature every cycle).

After completion of the touch down program, 25 cycles were subsequently performed $\left(94^{\circ} \mathrm{C}\right.$ for $30 \mathrm{~s}, 60^{\circ} \mathrm{C}$ for $20 \mathrm{~s}$ and $74^{\circ} \mathrm{C}$ for $45 \mathrm{~s}$ ) and ending with a $10 \mathrm{~min}$ extension at $74^{\circ} \mathrm{C}$. PCR reactions were run on a $0.8 \%$ agarose gel stained with ethidium bromide in $1 \mathrm{X}$ TBE. The observation for amplification at $1311 \mathrm{bp}$ was recorded using ultraviolet gel documentation system. 
Screening of $B$. subtilis isolates for their antimicrobial traits

Molecular detection for presence of biosynthetic gene coding for iturin

Molecular detection for presence of biosynthetic gene coding for iturin $\mathrm{D}$ was done against each $B$. subtilis isolates using Ituringene specific primers ItuD-F1 (TGAAYGTCAGYGCSCCTTT)/ ItuD-R1 (TGCGMAAATAATGGSGTCGT) (Chung $e t$ al., 2008; Venkatesan et al., 2015). A PCR reaction mixtures $(25 \mu \mathrm{l})$ was prepared each containing $1 \mathrm{X}$ PCR buffer with $1.5 \mathrm{mM} \mathrm{Mgcl}_{2}$; $200 \mu \mathrm{M}$ dNTPs; each 10pmol primer; $1 \mathrm{U}$ Taq DNA polymerase; bovine serum albumin (BSA) and $100 \mathrm{ng}$ bacterial DNA. PCR reaction mixtures $(25 \mu \mathrm{l})$ were transferred to a Mastercycler gradient (Eppendorf, Germany) with the following cycle conditions: initial denaturation at $95{ }^{\circ} \mathrm{C}$ for $15 \mathrm{~min}, 40$ cycles of $95 \mathrm{C}$ for $1 \mathrm{~min}, 52^{\circ} \mathrm{C}$ for $1 \mathrm{~min}$ and $72{ }^{\circ} \mathrm{C}$ extension for $1.5 \mathrm{~min}$ and a final extension at $72{ }^{\circ} \mathrm{C}$ for $7 \mathrm{~min}$. EachPCR reaction was analysed by electrophoresis using a $0.8 \%$ agarose gel stained with ethidium bromide and visualized under ultraviolet light for amplification at $482 \mathrm{bp}$.

Molecular detection for presence of biosynthetic gene coding for fengyncins

Each B. subtillis isolates were screened for presence of biosynthetic gene coding for fengyncins using fengycin gene specific primers FenB-F1 (CCTGGAGAAAGAATAT ACCGTACCY)/ FenB-R1(GCTGGTTCAGT TKGATCACAT) (Chung et al., 2008; Zokaeifar et al., 2014; Venkatesan et al., 2015). A PCR reaction mixtures $(25 \mu \mathrm{l})$ was prepared each containing $1 \mathrm{X}$ PCR buffer with $1.5 \mathrm{mM} \mathrm{MgCl} 2 ; 200 \mu \mathrm{M}$ dNTPs; each $10 \mathrm{pmol}$ primer; $1 \mathrm{U}$ Taq DNA polymerase; bovine serum albumin (BSA) and $100 \mathrm{ng}$ bacterial DNA. PCR reaction mixtures $(25 \mu \mathrm{l})$ were run with the following cycle conditions: initial denaturation at $95^{\circ} \mathrm{C}$ for $15 \mathrm{~min}, 40$ cycles of $95^{\circ} \mathrm{C}$ for $1 \mathrm{~min}, 55^{\circ} \mathrm{C}$ for $1 \mathrm{~min}$ and $72^{\circ} \mathrm{C}$ extension for $1.5 \mathrm{~min}$ and a final extension at $72^{\circ} \mathrm{C}$ for $7 \mathrm{~min}$. Each PCR reaction was analysed by electrophoresis using a $0.8 \%$ agarose gel stained with ethidium bromide and visualized under ultraviolet light for amplification at $670 \mathrm{bp}$.

\section{$\mathrm{HCN}$ production test}

Hydrogen cyanide $(\mathrm{HCN})$ production test was carried out for all the B. subtilis isolates. HCN production of bacterial bio-control agents was tested following the method of Bakker and Schipper (1987). The test bacteria were streaked into NA plates supplemented with glycine at $4.4 \mathrm{~g} / \mathrm{l}$ with simultaneous addition of filter paper (Watman No. 1) impregnated with $0.5 \%$ picric acid and $1 \%$ sodium carbonate $\left(\mathrm{Na}_{2} \mathrm{CO}_{3}\right)$ in the upper lids of the plates along with uninoculated control. Petri plates were sealed with parafilm and incubated at $28 \pm 1^{\circ} \mathrm{C}$ for $48 \mathrm{~h}$. Discolouration of the filter paper from yellow to brown after incubation were co-ordinated as microbial production of cyanide. Brown or reddish-brown was recorded as weak $(+)$, moderate $(++)$, strong $(+++)$ and negative (-) reaction respectively.

\section{Chitinase production}

The B. subtilis isolates were tested for chitinase production. Colloidal chitin was prepared from commercial chitin (HiMedia) by the method of (Mathivanan 1995; Shanmugaiah et al., 2008). In the first step, acid hydrolysis of commercial chitin was done by suspending $5.0 \mathrm{~g}$ of chitin in $60 \mathrm{ml}$ conc. $\mathrm{HCl}$ by constant stirring using a magnetic stirrer and stores at $4{ }^{\circ} \mathrm{C}$ (refrigerator) overnight. Second step was the extraction of colloidal chitin by ethanol neutralization. To the resulting slurry (as obtained in step one), 
$200 \mathrm{ml}$ of ice-cold $95 \%$ ethanol was added and kept at $26^{\circ} \mathrm{C}$ for overnight. It was then centrifuge at $3000 \mathrm{rpm}$ for $20 \mathrm{~min}$ at $4^{\circ} \mathrm{C}$. The pellet was washed with sterile distilled water by centrifugation at $3000 \mathrm{rpm}$ for $5 \mathrm{~min}$ at $4^{\circ} \mathrm{C}$. The washing of the pellets was done till the smell of alcohol vanished. Colloidal chitin thus obtained was stored at $4{ }^{\circ} \mathrm{C}$ until further use.

The final chitinase detection medium consisted of a basal medium comprising of (all amounts are per litre) $10 \mathrm{~g}$ of $1 \%$ colloidal chitin, $6 \mathrm{~g}$ of $\mathrm{NaH}_{2} \mathrm{PO}_{4}, 3 \mathrm{~g}$ of $\mathrm{KH}_{2} \mathrm{PO}_{4}, 0.5 \mathrm{~g}$ $\mathrm{NaCl}, 1 \mathrm{~g} \mathrm{NH}_{4} \mathrm{Cl}, 0.05 \mathrm{~g}$ Yeast extract, $15 \mathrm{~g}$ of agar, $\mathrm{pH}$ was adjusted to 6.5 and then autoclaved at $121^{\circ} \mathrm{C}$ for $15 \mathrm{~min}$. After cooling the medium was poured in to Petri plates and allowed to solidify. The fresh test bacterium was spot inoculated into the medium and incubated at $25 \pm 2{ }^{\circ} \mathrm{C}$. Chitinase production was detected by observing clear zones around the colonies after growth for 48-72 $\mathrm{h}$ and recorded for diameter of the clear zones (Cihan et al., 2012).

\section{Protease production}

B. subtilis isolates were tested for protease production. In screening for protease activity, the test bacterium was spot inoculated on Skim Milk agar (pH 7.0) plates and incubated at $37 \pm 1^{\circ} \mathrm{C}$ for $72 \mathrm{~h}$. Isolates which gave a clear zone around their colonies due to the hydrolysis of skim milk were selected (Cihan et al., 2012).

\section{Bio-assay of $B$. subtilis against Penicillium} sp.

B. subtilis isolates were screened for their antagonistic activity against Penicillum sp. isolated from Khasi mandarin (Penicillium rot infected fruit) by dual culture assay under invitro. A $0.1 \mathrm{~cm}$ agar plug from the margin of a growing fungal culture on a PDA plate was incubated centrally on a fresh PDA plate for $48 \mathrm{~h}$ at $24^{\circ} \mathrm{C}$. The test bacterium culture was grown with PDB, shaken at $250 \mathrm{rpm}$ for $24 \mathrm{~h}$ at $30^{\circ} \mathrm{C}$ then centrifuged at $4000 \mathrm{rpm}$ for 15 min and the pellet was streaked on the PDA plate $1 \mathrm{~cm}$ away from the fungal plug. Observations of the fungal reactions were recorded after 5 days and the radii of any zones of inhibition of the fungus were measured using a measuring scale. Three replicates were used for each $B$. subtilis isolate tested (Leelasuphakul et al., 2008). The percentage of hyphal growth inhibition was calculated using the following formula (Gamliel et al., 1989).

\section{$P I=100-\left[\left(R^{2} / C^{2}\right) \times 100\right]$}

Where,

PI = Percent percentage of hyphal growth inhibition

$\mathrm{R}=$ radius of treatment $(\mathrm{cm}) \mathrm{C}=$ radius of control $(\mathrm{cm})$

\section{Results and Discussion}

A total of 15 habitats have been selected for sample collection i.e. crop rhizosphere, hot springs, pig manure, river bank deposits, citrus fruit surfaces, mixed manure, coal mines, limestone mines, forest, leave mould, vermicompost, fishery ponds, oyster mushroom compost, jhum area and bio-extract. Majority of the isolates obtained, were isolated from samples collected from West Jaintia hills district (94) followed by East Khasi Hills (70), Ri-Bhoi district (51), West Garo Hills (20), North Garo Hills (10), West Khasi Hills (7), East Jaintia Hills (4) and South West Garo Hills (3). A total of 260 isolates were obtained from the different samples collected. Maximum isolates were obtained from crop rhizosphere (182), followed by limestone mines (14), coal mines (13), citrus fruit surfaces (10), river bank deposits (8), hot springs (5), forest (5), fishery ponds (5), oyster 
mushroom compost (5), mixed manure (4), pig manure (2 isolates), leave mould (2), vermicompost (2), bio-extract (2) and jhum area (1). Reports have been made since the 1970s which supports the findings, that Bacillus sp. are micro-organisms that exist as soil inhabitant (Mundt and Hinckle, 1976; Walker et al., 1998), inrhizosphere of plants (Zhang et al., 1996; Maheswar and Sathiyavani, 2012) and many other environment (Sneath 1986; McSpadden Gardener 2004) such as Brassica leaves (Leifertet al., 1992), compost (Phaeet al., 1990), citrus fruit surfaces (Obagwu and Korsten, 2003), textile wastewater (Gomaaand Azab., 2007), extreme environments such as hot, cold, acidic, alkali and saline areas (Cihan et al., 2012), as their survival is aided by this ability to form endospores.

A total of 260 isolates were obtained from samples collected from 8 districts of Meghalaya Morphology character of the colony of the isolates were creamish white colony, large with irregular edges, non- fluidal, shiny with smooth texture and slightly raised (Plate 1), 253 isolates were Gram staining positive, 95 isolates were positive to catalase test, 6 isolates showed positive to oxidase test (Plate 2). Hence, only 95 isolates were studied further for molecular identification. The finding can be supported as per the findings of Saleh et al., (2014) who reported that $B$. subtilis are straight or sometimes curved rods, Gram positive, catalase-positive bacilli. Similar findings were also reported by Yumoto et al., (1998) that $B$. subtilis are found to exhibit positive to catalase and oxidase activity.

Molecular identification of the isolates using of $16 \mathrm{~S}$ rRNA intervening sequence Bacillus sp. genus specific primer $\mathrm{BC} 1 \mathrm{R} / \mathrm{BC} 1 \mathrm{~F}$ revealed that 69 isolates were amplified at $546 \mathrm{bp}$ and were designated as Bacillus sp. isolates (Plate3). Several reports have been made for identification of Bacillus sp. using primerBC1R/BC1F which supports the findings of the present investigation (Cano et al., 1994; Rajendra and Samiyappan, 2008).

Table.1 B. subtilis isolates and habitat of origin

\begin{tabular}{|c|c|c|c|c|c|c|c|}
\hline S1 no. & Isolates & $\begin{array}{c}\text { Gram } \\
\text { staining }\end{array}$ & $\begin{array}{c}\text { Catalase } \\
\text { test }\end{array}$ & $\begin{array}{c}\text { Oxidase } \\
\text { test }\end{array}$ & Shape & Habitat & Location \\
\hline $\mathbf{1}$ & Bs 80 & + & + & + & $\mathrm{R}$ & Radish rhizosphere & West Garo Hills, Tura. \\
\hline $\mathbf{2}$ & Bs 167 & + & + & + & $\mathrm{R}$ & Brinjalrhizosphere & West Jaintia Hills, Mookyndeng. \\
\hline $\mathbf{3}$ & Bs 174 & + & + & + & $\mathrm{R}$ & Forest & East Khasi Hills (EKH), Mawphlang. \\
\hline $\mathbf{4}$ & Bs 190 & + & + & + & $\mathrm{R}$ & Mint rhizosphere & EKH, Upper Shillong. \\
\hline $\mathbf{5}$ & Bs 193 & + & + & + & $\mathrm{R}$ & Mixed manure & EKH, Upper Shillong. \\
\hline $\mathbf{6}$ & Bs 197 & + & + & + & $\mathrm{R}$ & Chilli rhizospher & EKH, Upper Shillong. \\
\hline $\mathbf{7}$ & Bs 216 & + & + & + & $\mathrm{R}$ & Fishery pond & Ri-Bhoi District, Sumer. \\
\hline $\mathbf{9}$ & Bs 217 & + & + & + & $\mathrm{R}$ & Fishery pond & Ri-Bhoi District, Sumer. \\
\hline $\mathbf{1 0}$ & Bs 219 & + & + & + & $\mathrm{R}$ & Oyster mushroom & EKH, Upper Shillong. \\
\hline $\mathbf{1 1}$ & Bs 256 & + & + & + & $\mathrm{R}$ & Fishery pond & Ri-Bhoi District, Umsning. \\
\hline $\mathbf{1 2}$ & COB5Y1 & + & + & + & $\mathrm{R}$ & Jhum area & Ri-Bhoi District CPGS, SCP Laboratory. \\
\hline
\end{tabular}

$(-)$ indicates negative to the test, $(+)$ indicates positive to the test, $(++)$ indicates strongly positive to the test, $\mathrm{R}=$ rod shaped 
Table.2 Antimicrobial properties of B. subtilis

\begin{tabular}{|c|c|c|c|c|c|c|c|}
\hline \multirow[t]{2}{*}{ Isolates } & \multicolumn{5}{|c|}{ Anti-microbial traits } & \multicolumn{2}{|c|}{$\begin{array}{l}\text { Dual culture test of } B \text {. subtilis against } \\
\text { Penicillium } \text { sp. }\end{array}$} \\
\hline & Fengycin B & Iturin D & HCN test & $\begin{array}{c}\text { Chitinase } \\
\text { test }\end{array}$ & Proteaase test & $\begin{array}{l}\text { Hyphal radial } \\
\text { growth }(\mathrm{cm})\end{array}$ & $\begin{array}{c}\text { Inhibition per cent } \\
(\text { PI \%) }\end{array}$ \\
\hline Bs 80 & - & - & - & - & - & $2.87 \pm 0.03^{\mathrm{a}}$ & $2.26 \pm 2.26^{\mathrm{ef}}$ \\
\hline Bs 167 & - & - & - & ++ & + & $1.27 \pm 0.07^{d}$ & $80.82 \pm 2.06^{a}$ \\
\hline Bs 174 & - & - & - & - & - & $2.17 \pm 0.07^{\mathrm{bc}}$ & $44.07 \pm 3.49^{\mathrm{bc}}$ \\
\hline Bs 190 & - & - & - & - & + & $2.57 \pm 0.28^{\mathrm{ab}}$ & $19.74 \pm 1.47^{\mathrm{de}}$ \\
\hline Bs 193 & - & - & - & - & + & $2.57 \pm 0.12^{\mathrm{ab}}$ & $21.32 \pm 7.47^{\mathrm{cd}}$ \\
\hline Bs 197 & - & - & - & + & + & $1.93 \pm 0.18^{c}$ & $54.82 \pm 7.92^{b}$ \\
\hline Bs 216 & - & - & - & - & + & $2.23 \pm 0.12^{b c}$ & $40.35 \pm 6.26^{\mathrm{bc}}$ \\
\hline Bs 217 & - & - & - & ++ & + & $2.23 \pm 0.15^{b c}$ & $40.19 \pm 7.81^{\text {bc }}$ \\
\hline Bs 219 & - & - & - & ++ & + & $2.50 \pm 0.25^{\mathrm{ab}}$ & $24.18 \pm 14.26^{\text {cd }}$ \\
\hline Bs 256 & - & - & - & + & + & $2.27 \pm 0.09^{\mathrm{bc}}$ & $38.72 \pm 4.70^{\mathrm{bc}}$ \\
\hline Bs 257 & - & - & - & - & + & $2.23 \pm 0.15^{b c}$ & $40.19 \pm 7.81^{\text {bc }}$ \\
\hline COB5Y1 & - & - & - & ++ & + & $1.00 \pm 0.00^{d}$ & $88.11 \pm 0.00^{\mathrm{a}}$ \\
\hline Control & - & - & - & - & - & $2.90 \pm 0.00^{\mathrm{a}}$ & $00.0 \pm 0.00^{\mathrm{f}}$ \\
\hline SEM & & & & & & 0.14 & 7.83 \\
\hline $\mathrm{CD}$ at $5 \%$ & & & & & & 0.41 & 22.77 \\
\hline
\end{tabular}

Values in column with common letters do not differ significantly as determined by the one-way ANOVA at 5\% level of significance.

Plate.1 B. subtilis isolate

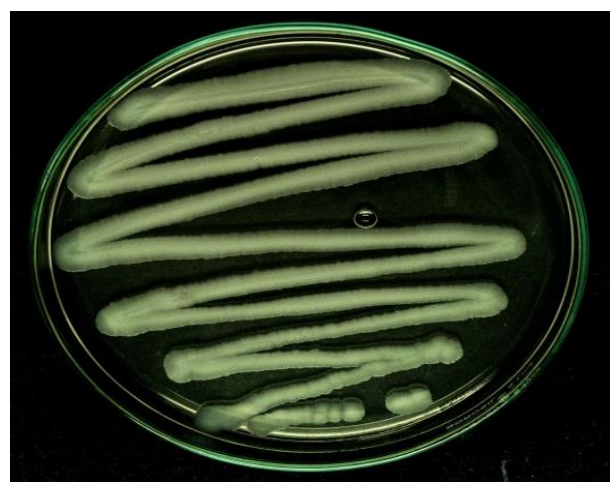

Colony morphology of $B$. subtilis isolate

Plates.2 Biochemical identification

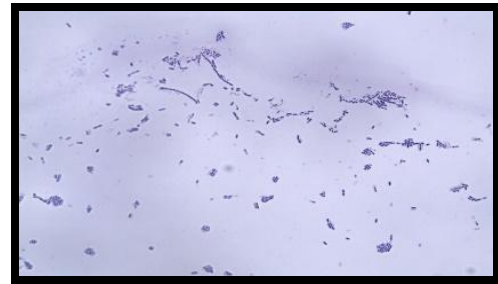

Gram staining test

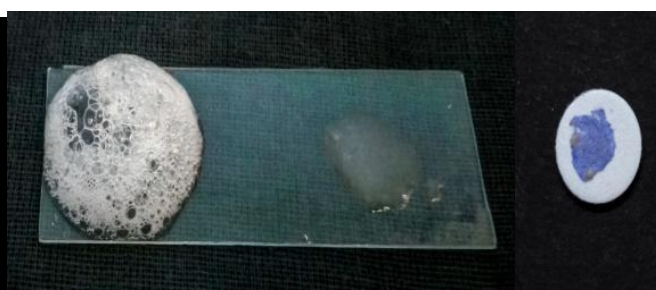

Catalase test
Oxidase test 
Plates.3 Molecular identification Bacillus sp. specific primer

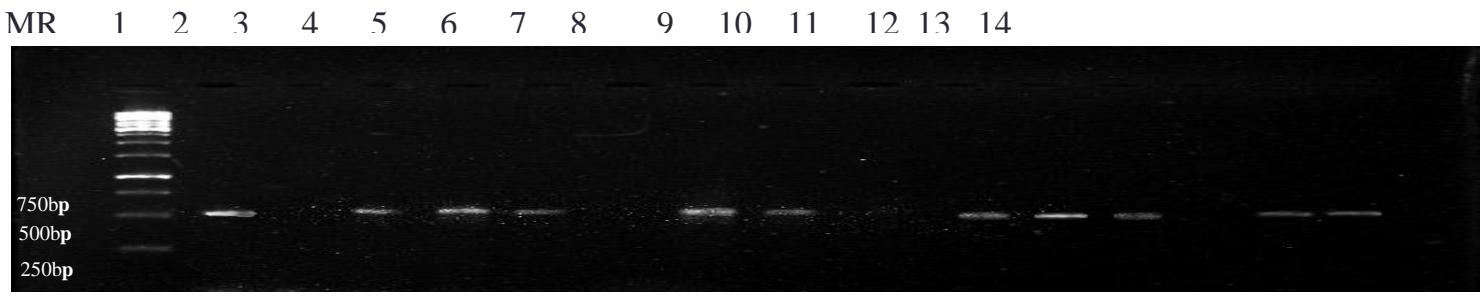

$\begin{array}{lllllllllllllll}\text { M R } & 15 & 16 & 17 & 18 & 19 & 20 & 21 & 22 & 23 & 24 & 25 & 26 & 27 & 28\end{array}$

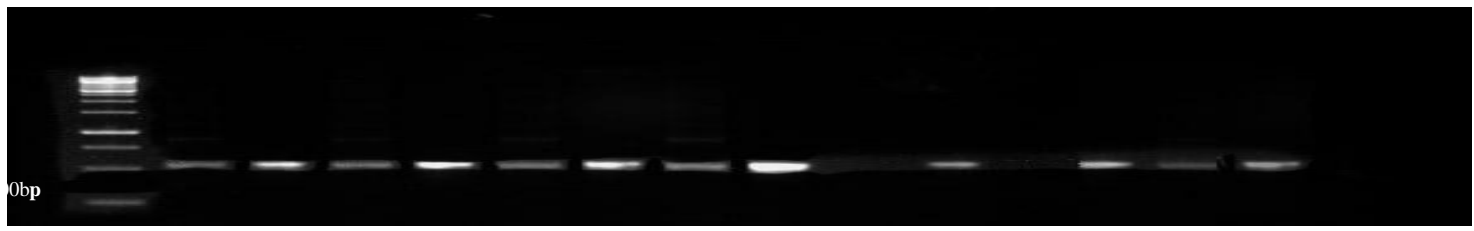

$\begin{array}{lllllllllllllll}\text { MR } & 29 & 30 & 31 & 32 & 33 & 34 & 35 & 36 & 37 & 38 & 39 & 40 & 41 & 42\end{array}$

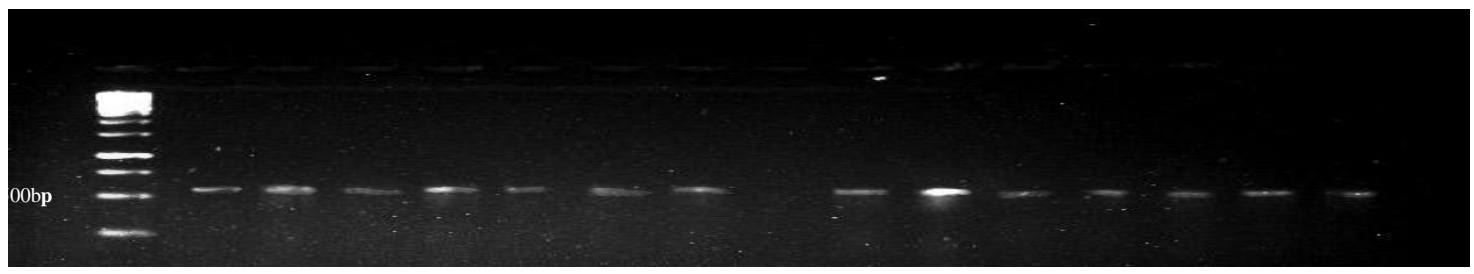

$\begin{array}{lllllllllllllll}\text { MR } & 43 & 44 & 45 & 46 & 47 & 48 & 49 & 50 & 51 & 52 & 53 & 54 & 55 & 56\end{array}$
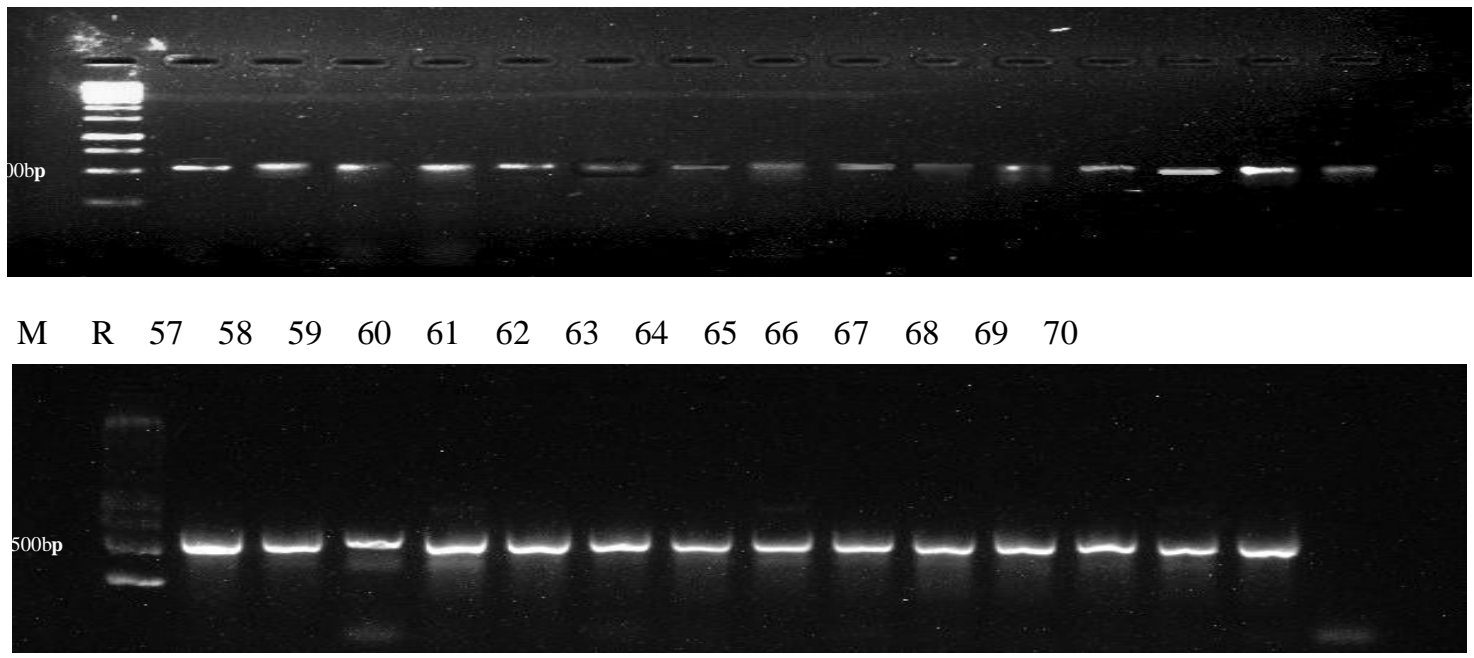

$\begin{array}{lllllllllllllll}\text { M R } & 71 & 72 & 73 & 74 & 75 & 76 & 77 & 78 & 79 & 80 & 81 & 82 & 83 & 84\end{array}$

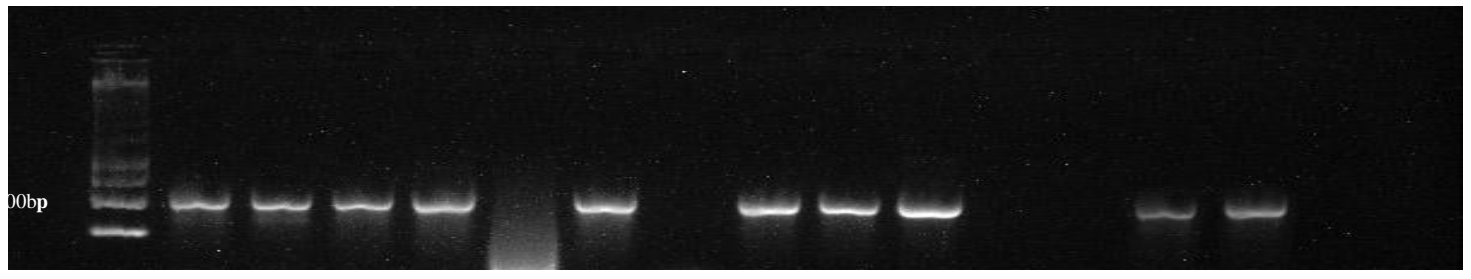

Bacillus sp. isolates showing amplification at 546bp to primer BCF1/BCR1.M=1kb ladder; $\mathrm{R}=$ positive reference; Bacillus sp. (+) isolates lane no.= 2-4, 6, 7, 9-11, 13-21, 23, 25-27, 29-34, 36-69, 71-73, 75, 77-79, 82-83 
Plates.4 Molecular identification Bacillus subtilis specific primer
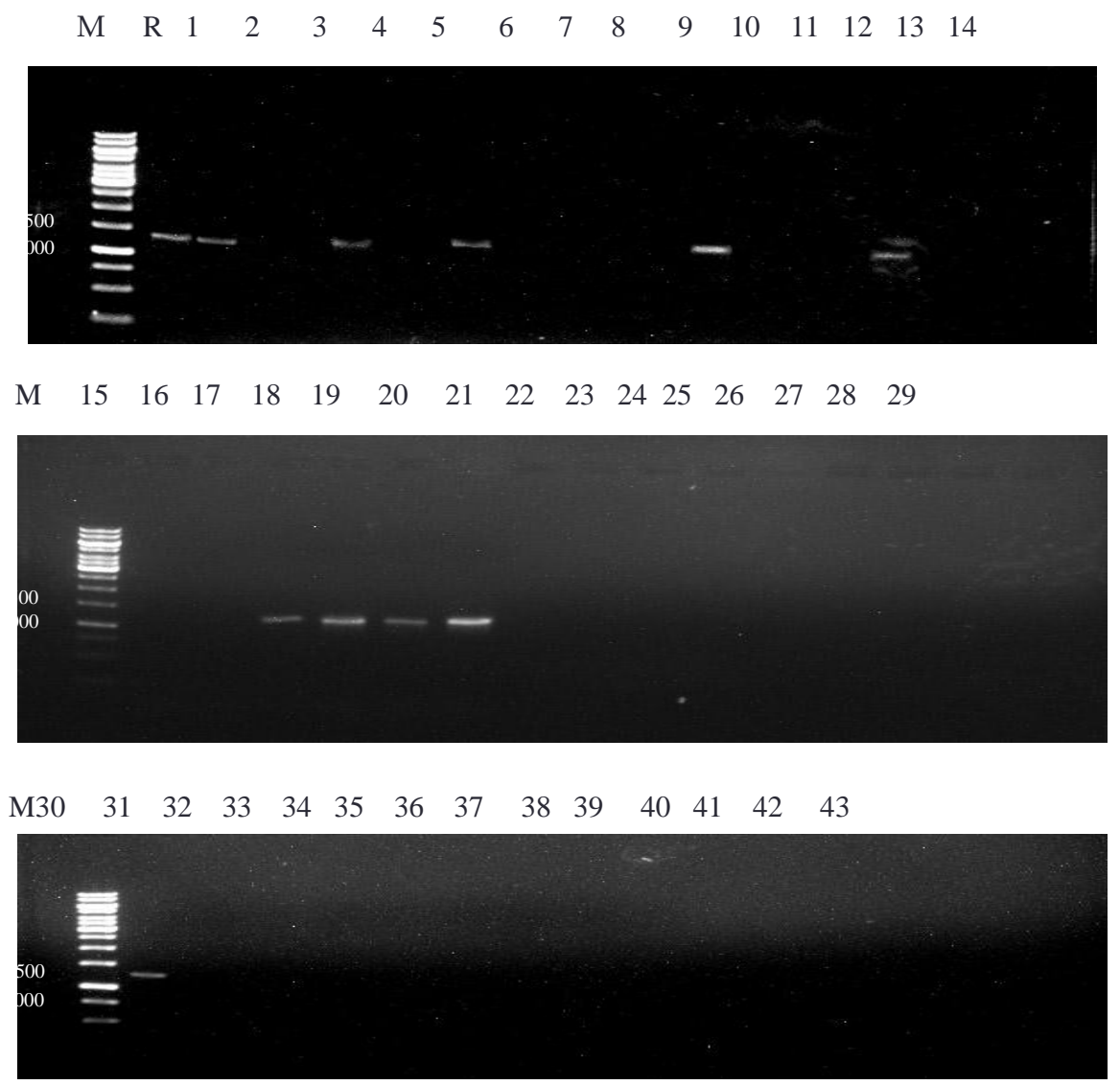

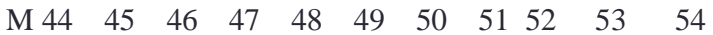

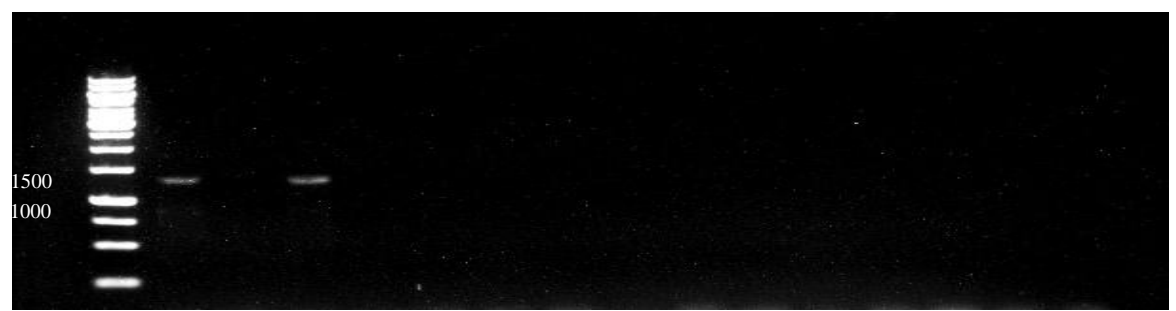

B. subtilis isolates showing amplification at $1311 \mathrm{bp}$ to primer $\mathrm{EN} 1 \mathrm{~F} / \mathrm{EN} 1 \mathrm{R} . \mathrm{M}=1 \mathrm{~kb}$ ladder; $\mathrm{R}=$ positive reference; B.subtilis (+) isolates lane no. 1=Bs 80, 3=Bs 167, 5=Bs 174, 9=Bs 190, 12=Bs 193, 17=Bs 197, 18=Bs 216, 19=Bs $217,20=B s 219,30=B s 256,44=B s 257$ and $46=$ COB5Y 1 .

Plate.6 Bio-assay for antimicrobial activity against Penicillum sp.

Dual culture test (a) test bacterium (b) Control

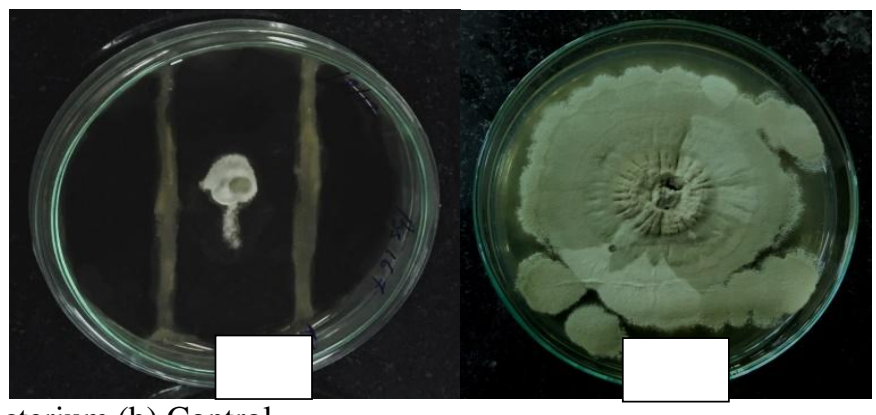


Plate.5 Antimicrobial tests of $B$. subtilis isolates

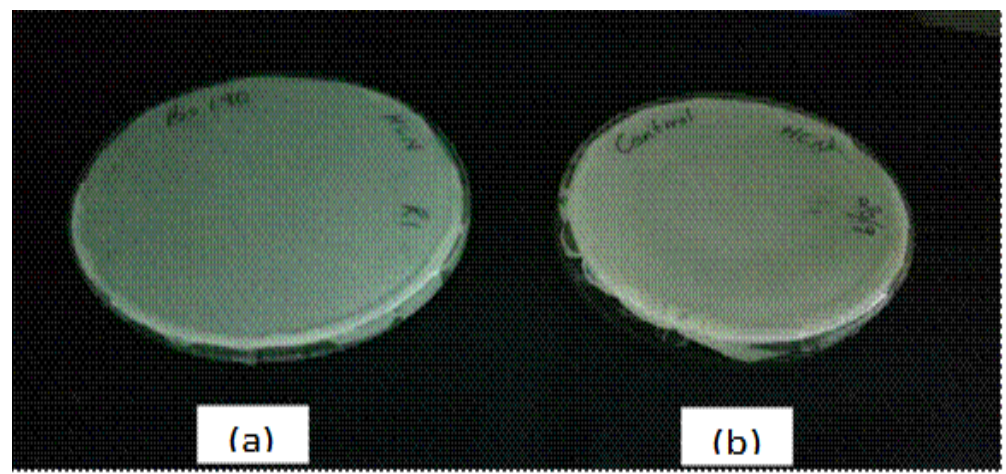

HCN production test (a) positive (b) negative

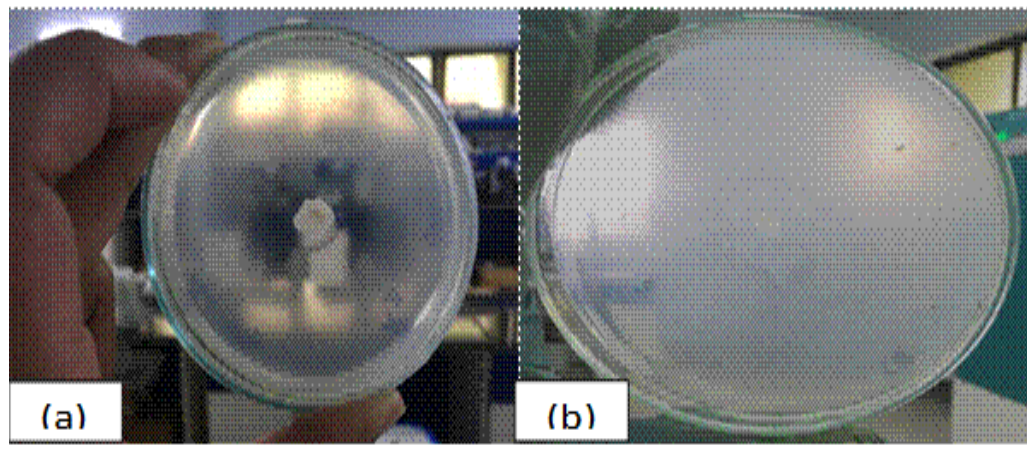

Chitinase production test (a) positive (b) negative

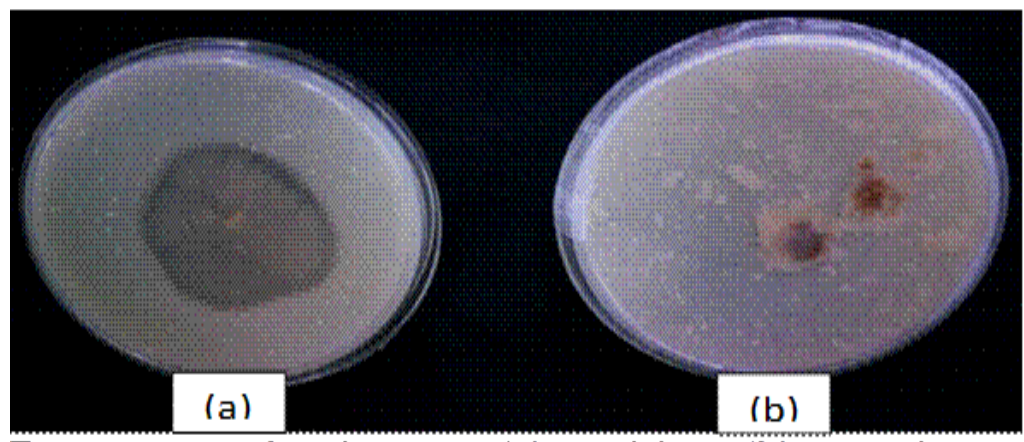

Protease production test (a) positive (b) negative

Bacillus sp. isolates were further confirm as B. subtilis isolates using species specific primer EN1F/EN1R which identified 12 isolates as B. subtilis (Bs 80, Bs 167, Bs 174, Bs 190, Bs 193, Bs 197, Bs 216, Bs 217, Bs 219, Bs 256, Bs 257 and COB5Y1) (Table 1, Plate 4). The findings can be supported as per the reports of Ashe et al., (2014).

Antimicrobial traits studied against each of the $12 \mathrm{~B}$. subtilis isolates revealed that all $B$. subtilis isolates were negative to biosynthetic antibiotic gene coding for iturinD and fengycinB. Twelve of the isolates were negative to $\mathrm{HCN}$ production, six isolates were positive to chitinase test and 10 isolates were positive to protease test (Table 2, Plate 5). Based on the antimicrobial traits, 6 B. subtilis isolates (Bs 167, Bs 197, Bs 217, Bs 219, Bs 256 and COB5Y1) were found with potential antagonistic properties as they were tested positive to chitinase and protease production. 
Reetha et al., (2014) reports supports the findings of the present investigation that none of the isolates of $B$. subtilis produce $\mathrm{HCN}$ but they showed efficacy against the pathogen M.phaseolina with 61.13- 63.36 per cent reduction over control. Production of chitinase and protease increase chitinase and protease inhibitory activities against the fungal pathogen (Vishwanathan and Samiyappan, 2002; Rajendra and Samiyappan, 2008; Liu et al., 2010) and supports the findings of the present investigation.

Dual culture assay revealed that COB5Y1 had the smallest diameter of radial growth with only $1.00 \mathrm{~cm}$ followed by Bs 167 with 1.27 $\mathrm{cm}$ and Bs 197 with $1.93 \mathrm{~cm}$. COB5Y1 was recorded with the highest disease inhibition per cent against Penicillium sp. with $88.11 \%$ followed by Bs 167 (80.82\%) and Bs 197 (54.82\%) (Table 2, Plate 6). Based on in-vitro evaluation, isolates COB5Y1, Bs 167 and Bs 197 were considered potential B. subtilis isolates amongst the $12 \mathrm{~B}$. subtilis isolates as they showed maximum percentage of inhibition against the growth of Penicillium sp. The findings that $B$. subtilis could inhibit post-harvest fungal pathogen Penicillium sp. as well as other toxic fungus can be supported as per the findings of Yoshida et al., (2001), Leelasuphakul et al., (2008), Arrebola et al., (2009) and Bharose et al., (2017).

Judging by the anti-microbial traits and the bioassay of the $12 \mathrm{~B}$. subtilis isolates, 4 isolates COB5Y1, Bs 167, Bs 197 and Bs 217were found with potential antagonistic properties as they could produce chitinase and protease and also were recorded with the maximum percentage of inhibition in dual test.

In conclusion, $B$. subtilis is found to exist in different natural habitats other than the soil. B. subtilis has a great potential in the bio control management of the post-harvest Penicillium rot pathogen Penicillium sp. of Khasi mandarin. The four potential B. subtilis isolates COB5Y1, Bs 167, Bs 197 and Bs 217 could serve as potential bio-agent against post-harvest Penicillium rot of Khasi mandarin in Meghalaya which needs further post-harvest evaluation under field condition.

\section{References}

Anonymous, 2011.National Horticulture Board, Horticulture Information Service.

Anonymous, 2013. National Horticulture Board, Indian Horticulture Database.

Arrebola, E., R. Jacobs and Korsten, L. 2009. Iturin $\mathrm{A}$ is the principal inhibitor in the biocontrol activity of Bacillus amyloliquefaciens PPCB004 against postharvest fungal pathogens. J. Applied Microbiol. 108 (2010): 386395.

Arul, J. 1994. Emerging technologies for the control of postharvest diseases of fresh fruits and vegetables. In: Biological Control of Postharvest Diseases-Theory and Practice (Eds.) C.L.Wilson and M.E Wisniewski. CRC Press, Inc. Pp. 1-6.

Ashe, S., U. J. Maji, R. Sen, S. Mohanty and Maiti, N.K. 2014. Specific oligonucleotide primers for detection of endoglucanase positive Bacillus subtilis by PCR. 3 Biotech. 4:461-465.

Barman, K. 2010. Survey and management of post-harvest diseases of Khasi mandarin (Citrus reticulate Blanco) in Meghalaya. Thesis, College of Post Graduate Studies, School of Crop Protection, Umiam, Meghalaya.

Bharose, A.A., H.P. Gajera, D.G. Hirpara, V.H. Kachhadia and Golakiya, B.A. 2017. Molecular Identification and Characterization of bacillus antagonist to inhibit aflatoxigenic Aspergillus flavus. Int. J. Curr. Microbiol. App. 
Sci.6(3): 2466-2484.

Cano, J.R., M.K. Borucki, M.H. Schweitzer, H.N. Poinar, G.O. Poinar Jr. and Pollard J.K. 1994. Bacillus DNA in Fossil Bees: an Ancient Symbiosis. Appl. Environ. Microbiol. 60: 2164-2167.

Chung, S., H. Kong, J.S. Buyer, D.K. Lakshman, J. Lydon and Kim S.D. 2008. Isolation and partial characterization of Bacillus subtilis ME488 for suppression of soilborne pathogens of cucumber and pepper. Appl. Microbiol. Biotechnol. 80(1):115-23.

Cihan, C.A., T. Nilgun, O. Birgul and Cumhur C. 2012.The genetic diversity of genus Bacillus and the related genera revealed by $16 \mathrm{~s}$ rRNA gene sequences and ARDRA analyses isolated from geothermal regions of Turkey. Brazilian Journal of Microbiol. 309-324.

Eckert, J.W. 1990. Recent developments in the chemical control of postharvest disease.ActaHortic. 269: 477.

Eckert, J.W., and Brown, G.E. 1986. Postharvest citrus diseases and their control. In Fresh Citrus Fruits (Eds) W. F. Wardowski, S. Nagy and W. Grierson. New York: Van Nostrand Reinhold Company Inc. Pp. 315-360.

Fiddaman, P.J., and Rossall, S. 1993. The production of antifungal volatiles by Bacillus subtilis. J. Appl. Bacteriol. 74: 119-126.

Gamliel, A., J. Kantan and CohonE. 1989. Toxicity of choronitrobenzenes to Fusarium oxysporum and Rhizoctonia solani as related to their structure. Phytoparasitica. 17: 101-106.

Gomaa, M.O., and Momtaz, A. O. 2007. 16S rRNA characterization of a Bacillus isolate and its tolerance profile after subsequent subculturing. Arab J. Biotech., 10(1): 107-116.

Gomaa, O., and Azab, K. Sh. 2007.Resistance to hydrogen peroxide in textile wastewater Bacillus sp. International Journal of Agriculture and Biology.(In Press).

Holt, J.G, N.R. Krieg, P.H.A. Sneath, T.J. Staley and Williams S.T. 1994. In: Bergey's Manual of Determinative Bacteriology (9th Eds.)Baltimore: Williams and Wilkins. Pp. 559.

Jamil, B., F. Hasan, A. Hameed and Ahmed S. 2007.Isolation of Bacillus subtilis MH-4 from soil and its potential of polypeptidic antibiotic production. Pak. J. Pharm. Sci.20(1): 26-31.

Jiang, Y.M., X.R. Zhuand Li, Y.B. 2001.Postharvest control of litchi fruit rot by Bacillus subtilis. Lebensm. Wiss. U.-Technol. 34: 430-436.

Knox, O.G.G., K. Killham and Leifert, C. 2000. Effects of increased nitrate availability on the control of plant pathogenic fungi by the soil bacterium Bacillus subtilis. Appl. Soil Ecol. 15: 227-231.

Kumar, P., R.C. Dubey and Maheshwari D.K. 2012. Bacillus strains isolated from rhizosphere showed plant growth promoting and antagonistic activity against phytopathogens. Microbiol.Res. 167: 493-499.

Leelasuphakul, W., P. Hemmaee and Chuenchitt, S. 2008.Growth inhibitory properties of Bacillus subtilis strains and their metabolites against the green mold pathogen (Penicillium digitatum Sacc.) of citrus fruit. Postharvest Biol. and Technol. 48: 113-121.

Leifert, C., D.C. Sigee, S A.H. Epton, R. Stanley and Knight, C. 1992. Isolation of bacteria antagonistic to postharvest fungal diseases of cold stored Brassica spp. Phytoparasitica. 20: 143-149.

Liu, B., H.Lili, B. Heinrich and Kang Z. 2010. Isolation and partial characterization of an antifungal protein from the endophytic Bacillus subtilis strain EDR4. Pesticide Biochem. 
Physiol. 98: 305-311.

MaheswarN. U., and. Sathiyavani, G. 2012.Solubilization of phosphate by Bacillus sps, from groundnut rhizosphere (Arachis hypogaea L). J. Chem. Pharmaceutical Res. 4(8):40074011.

Mathivanan, N. 1995.Studies on extracellular chitinase and secondary metabolites produced by Fusarium chlamydosporum, an antagonist to Puccinia arachidis, the rust pathogen of groundnut. Ph. D. thesis, University of Madras, Chennai, India.

McSpadden Gardener, B.B. 2004.Ecology of Bacillus and Paenibacillus spp. in agricultural systems. Phytopathol. 94: 1252-1258.

Mundt, J.O., and Hinckle, N.F. 1976.Bacteria within ovules and seeds. Applied and Environmental Microbiol. 32: 694-698.

Munich, L. 2014. Isolation of chromosomal DNA from Bacillus subtilis for transformation. http://2014.igem.org/ Team:LMU-Munich.

Obagwu, J., and Korsten, L. 2003. Integrated control of citrus green and blue molds using Bacillus subtilis in combination with sodium bicarbonate or hot water. Postharvest Biology and Technol. 28: 187-194.

Phae, C.G., M. Saski, M. Shodaand Kubota, H. 1990. Characteristics of Bacillus subtilis isolated from composts suppressing phytopathogenic microorganisms. Soil Sci. Plant Nutr. 36: 575-586.

Pinchuk, I.V., P.Bressollier, I.B. Sorokulova, B. Verneuil and Urdaci, M.C. 2002.Amicoumacin antibiotic production and genetic diversity of Bacillus subtilis strains isolated from different habitats. Res. Microbiol. 153: 269-276.

Rajendran, L., and Samiyappan, R. 2008. Endophytic Bacillus species confer increased resistance in cotton against Damping off disease caused by Rhizoctonia solani. Plant Pathol. J.7(1): 1-12.

Saleh, F., F.Kheirandish, H. Azizi, and Azizi, M. 2014. Molecular Diagnosis and Characterization of Bacillus subtilis Isolated from Burn Wound in Iran. Res. Mol. Med. 2 (2): 40-44.

Schaad, N.W. 1992. Laboratory guide for identification of plant pathogen bacteria. In: International Book Distribution Co., (2 ${ }^{\text {nd }}$ Eds.) Lucknow. Pp. 44-58.

Schippers, B., A.W. Bakker and Bakker M. H. A. P.1987. Interactions of deleterious and beneficial rhizosphere microorganisms and the effect of cropping practices. Annu. Rev. Phytopathol. 25:339-358.

Selvakumar, R.2011. Pseudomonas syringae for management of post harvest rot in Khasi mandarin oranges. Plant Dis. 26(2): 183-184..

Shanmugaiah, V., N. Mathivanan, N. Balasubramanian and Manoharan P.T. 2008. Optimization of cultural conditions for production of chitinase by Bacillus laterosporous MML2270 isolated from rice rhizosphere soil. African J. Biotechnol., 7(15): 25622568.

Singh, S., 2001.Citrus industry in India. In: Citrus International Book Distributing Company (Eds.) S. Singh and Naqvi S. A. M. H. Lucknow, India. Pp. 3-41.

Sneath, P.H.A. 1986.Endospore-forming Gram-positive rods and cocci. In: Bergey's Manual of Systematic Bacteriology (Eds.) P.H.A. Sneath, N.S. Mair, M.E. Sharpe and J.G. Holt. Baltimore: Williams \& Wilkins. Pp. 2: 1104-1207.

Sushma, K., A. Lama, B. Popescu, and Nakano M.M. 2012. Global Transcriptional Control by NsrR in 
Bacillus subtilis iGEM. J. Bacteriol. 194(7): 1679-1688.

Venkatesan, S., K. Gandhi, R. Thiruvengadam and Kappusami $P$. 2015. Identification of antifungal antibiotics genes of Bacillus species isolated from different microhabitat using polymerase chain reaction. African J. of Microbiol. Res. 9(5): 280285.

Viswanathan, R., and Samiyappan, R. 2002. Induced systemic resistance by fluorescent pseudomonads against red rot disease of sugar cane caused by Collectotrichum falcatum. Crop Prot. 21: $1-10$.

Walker, R., A.A. Powell and Seddon, B. 1998. Bacillus isolates from the spermosphere of peas and dwarf French beans with antifungal activity against Botrytis cinerea and Pythium species. Annals of Bot. 82(6): 721-725.

Yoshida, S., S. Hiradate, T. Tsukamato, K. Hatakeda and Shirata, A. 2001.
Antimicrobial activity of culture filtrate Bacillus amyloliquefaciens RC-2 isolated from mulberry leaves. Phytopathol. 91: 181-187.

Yumoto, I., K. Yamazaki, I.K. Kawasaki, N. Chise, N. Morita, T. Hoshino and Okuyama, H. 1998.Isolation of Vibrio sp. S-1 exhibiting extraordinarily high catalase activity. J. Ferment. Bioeng, 85(1):113-116.

Zhang, F., N. Dashti, K.R. Hynes and Smith, D.I. 1996. Plant Growth Promoting Rhizobacteria and Soybean (Glycine $\max$ (L.) Merr.) Nodulation and Nitrogen Fixation at Suboptimal Root Zone Temperatures. Ann. Bot. 77: 453460.

Zokaeifara, H., N. Babaeia, C.R. Saad, M.S. Kamarudin, K. Sijam and Balcázar L.J. 2014. Detection and identification of antibiotic biosynthesis genes in Bacillus subtilis strains. Biocontrol. Science and Technol. 24(2): 233-240.

\section{How to cite this article:}

Janshame Tariang, D. Majumder and Papang, H. 2018. Efficacy of Native Bacillus subtilis against Postharvest Penicillium Rot Pathogen Penicillium sp. of Khasi Mandarin Oranges in Meghalaya, India. Int.J.Curr.Microbiol.App.Sci. 7(12): 447-460.

doi: https://doi.org/10.20546/ijcmas.2018.712.056 